\title{
RELATIONSHIP BETWEEN ETHICAL CORPORATE SOCIAL RESPONSIBILITY AND CUSTOMER LOYALTY: THE MEDIATING ROLE OF CUSTOMERS' GRATITUDE
}

\author{
Abdelsalam Adam Hamid \\ International maritime college, Oman \\ E-mail: sunmust87@gmail.com \\ Maigana Amsami \\ Sudan University of Science and Technology, Sudan \\ E-mail:mgamsami@gmail.com \\ Siddiq Balal Ibrahim \\ Faculty of Business, Bahrain \\ E-mail: siddiq.ibrahim@aou.org.bh
}

Submission: $11 / 29 / 2020$ Accept: 1/8/2021

\section{ABSTRACT}

The purpose of this study was to examine whether customer gratitude mediates the association between ethical corporate social responsibility and customer loyalty. A cross-sectional survey was adopted. A total of 430 individual customers of retail banks located in some selected towns in north-east region of Nigeria were selected using convenience sampling. Structured questionnaires were used to collect. Descriptive statistics and partial least square structural equation modeling were used in data analysis. Finding showed that ethical corporate social responsibility positively and significantly affected customer loyalty. Also, a positive and significant effect of ethical corporate social responsibility on customer gratitude was observed. Furthermore, it was observed that customer gratitude and customer loyalty are positively associated. Also, customer gratitude mediated between ethical corporate social responsibility and customer loyalty. This study concluded that customer gratitude mediated the influence of ethical corporate social responsibility on customer loyalty. The finding of this study will help managers of Nigerian retail banks to develop ethical corporate social practices which strongly create feelings of gratitude among their banks' customers in order to take advantage of customers' gratitude, and eventually cultivate customers' loyalty. 
INDEPENDENT JOURNAL OF MANAGEMENT \& PRODUCTION (IJM\&P)

http://www.ijmp.jor.br

v. 12, n. 8, November-December 2021

ISSN: 2236-269X

DOI: 10.14807/ijmp.v12i8.1502

Keywords: Corporate Social Responsibility Customer; Ethical Social Responsibility; Gratitude; Loyalty; Retail Bank

\section{INTRODUCTION}

The modern business environment is facing an increasing demand for ethical behavior. As a result, companies including, banks, are seeking to integrate ethical manners into their business models. A business firm that acts ethically is differentiated from others by the public at large and is able to create a sustainable competitive advantage in marketplace by its good ethical behaviour (Nicolaides, 2018; Mostafa \& ElSahn, 2016; Aramburu \& Pescador, 2017).

Specifically, in the banking sector, ethical and transparent behaviors, and responsible financial products ensure its expected and dependable business (Lentner, Szegedi \&Tatay, 2015). Consequently, managers and academicians have put greater interest in considering ethical corporate social responsibility (ECSR) as a vital business strategy in terms of ECSR potential positive impact on customers (Romani, Grappi \& Baggozi, 2013). ECSR is a component of the broader corporate social responsibility [CSR] (Carroll, 1991). ECSR refers to all those values that mirror and respect what customers, the society and other business stakeholders look upon as accepted regarding the protection of their moral rights (Carroll, 2016).

ESCR practices help to generate customers' loyalty toward business organizations (Lee, Chang \& Lee, 2017; Kodua, Narteh, Braimah \& Mensah 2016). Hence, every business institution aims to attract loyal customers to ensure business success because a large loyal customers' base means a financially stable company that receives higher profits, and growing sales, among others (Išoraitè, 2016; Pan, Sheng \& Xie, 2012). Moreover, ESCR significantly influences customer gratitude (Romani, et al., 2013; Xie \& Bagozzi, 2014).

Gratitude is a moral emotion that arises in individuals when something beneficial is received from another person (McCullough, Kimeldorf \& Cohen, 2008). The ability to generate gratitude gives rise to beneficial action from the beneficiary towards the benefactor (Barlett \& DeSteno, 2006). Thus, ECSR actions such as respecting customers' moral rights can generate feelings of gratitude in customers. Subsequently, gratitude felt makes them respond positively with gratitude-based reciprocal action such as customer loyalty (Park \& Choi, 2016; Romani, et al., 2013).

Due to the growing recognition of the significance of ECSR practices in business, and to enhance the practice of ECSR, researchers had examined the mediation of gratitude on the 
DOI: 10.14807/ijmp.v12i8.1502

relationship between ECSR and customer positive outcomes. Xie, Baggozi and Gronhaug (2019) investigated the mediating role of gratitude in explaining the effect of ECSR on consumers' brand advocacy behaviors in offshore shipping company.

Finding has shown positive mediation of gratitude. Similarly, Xie and Bagozzi (2014) investigated the intervening role of gratitude on consumer decision to support nonprofits organization in the perspective of offshore shipping services. Result revealed positive mediation of gratitude. Romani et al. (2013) examined the mediating role of gratitude in explaining the influence of ECSR on consumers' recommendation and advocacy behaviors in a fictitious cocoa manufacturing company. Results revealed positive mediating role of consumers' gratitude on the relationship between ECSR and consumers' recommendation and advocacy behaviors.

Nevertheless, little is known on the mediating role of customer gratitude on the association between ECSR and customer loyalty in the banking industry, especially in northeast Nigeria. Therefore, the core objective of this study was to examine the mediating role of customer gratitude on the effect of ECSR practices of Nigerian retail banks on their customers' loyalty. Thus, the effect of ECSR practices on customers' loyalty was examined; the effect of ECSR practices on customers' gratitude; the relationship between customers' gratitude and customers' loyalty, and the mediation mechanism of customers' gratitude on the association between ECSR practices and customers' loyalty were investigated.

It is valuable to understand the mediation effect of customers' gratitude on the association between ECSR and customers' loyalty in the banking sector because the ECSR dimension might have a different outcomes on industries depending on the sensitivities of each industry (Goyal \& Chanda, 2017). This study focuses on the banking sector as a reference point because the banking sector is an important sector providing retail banking services and having the potentials to attract and manage substantial economic resources in the nation's economy.

More importantly, the banking sector was chosen because the Nigerian financial system is dominated by the banking sector, which represents 75 percent of the system's assets, and the banking sector's assets stood at 32.43 trillion nairas as of March 2017 (World Bank Group, 2017). Additionally, the banking index was the best performing sector in 2017, up73.3\% (Afrinvest, 2018).

The contribution of this study is from both theoretical and managerial perspectives: theoretically, the study provides a new explanation by associating ECSR, customer gratitude, 
DOI: 10.14807/ijmp.v12i8.1502

and customer loyalty, hence contributing to the theory, and regarding managerial contribution, it provides practical knowledge of how ECSR is developed and implemented to increase customer loyalty using the mediating mechanism of customer gratitude.

This paper is organized into seven sections as follows: Section I is the introduction, section II dwells on literature review. In this section, constructs of the study are discussed, section III dwells on theoretical framework of the study, hypotheses development and presents a conceptual model of the study, section IV discusses the methodology of the study, section V present results, and section VI dwells on the discussion of the findings, theoretical and managerial implications, limitations of the study and suggestions for future study, and conclusion.

\section{LITERATURE REVIEW}

\subsection{Ethical Corporate Social Responsibility (ESCR)}

Before defining ECSR, related expressions such as corporate social responsibility (CSR) require elucidation. CSR is defined in various ways in the literature. However, Carroll's (1979) explanation is extensively accepted (McCain, et al., 2019). Thus, the present study adopted this viewpoint. Carroll (1979) defines CSR as "the social responsibility of business encompasses the economic, ethical, legal and discretionary expectations that society has of organizations at a given time” (p.500). However, Carroll (1991) revisited the 1979 model, and renamed the discretionary responsibility as philanthropic responsibility.

Carroll (1991) defines ECSR as doing business in a way consistent with anticipations of society's norms and ethics (Carroll, 1991). A business has the expectation, and obligation, that it will perform what is right, just, and fair and to shun damage with whom it interacts (Carroll, 2016, p.4). Carroll (1991) highlighted the significant components of these responsibilities to include performance in a way consistent with the anticipations of society's norms and ethics, recognizing and valuing new or evolving ethical/ moral norms adopted by society, protect ethical norms from being compromised to attain organizational goals, understanding that corporate citizenship as performing what is expected morally and ethically, and recognizing that corporate integrity and ethical conduct go above the simple observance of laws and regulations. In the banking sector, Lentner, Sezdegi and Tatay (2015 maintain that ECSR concerns the fundamental values of integrity, fair conduct, respect, and transparency in the banking sector. 
DOI: 10.14807/ijmp.v12i8.1502

CSR proponents view the ethical company as an enterprise that fruitfully integrates society's interests (Berenbeim, 2006). Moss (2002) maintains that businesses are learning that generating profits is based upon an ethical base. García de los Salmones and Rodríguez del Bosque (2011) claim that the perception of ethically responsible behavior leads to positive associations that translate into an excellent evaluation of service. Hence, ECSR is a right way of differentiation as well as a powerful tool of creating affective responses which support loyalty. ECSR initiatives offer benefits to companies which include purchase seeking, advocacy, building positive corporate image, an customer loyalty (Du, Bhattacharya \& Sen, 2010; Lee, et al., 2017; Stanisavljević, 2017; McCain et al., 2018).

\subsection{Customer Loyalty}

Pan, Sheng and Xie (2012) define customer loyalty as "loyalty is the strength of a customer's dispositional attachment to a brand (or a service provider) and his/her intent to rebuy the brand (or repatronise the service provider) consistently in the future” (p.151). Kim and Kim (2016) aver that customer loyalty results in recommendation of a firm's products or services using positive word- of-mouth. More importantly, in the modern business world, competition is high, so every company aims to attract loyal customers to ensure business success.

Hence, customer loyalty is regarded as one of the most effective strategies (Išoraite, 2016). García de los Salmones and Rodríguez del Bosque (2011) aver that perception of ethically responsible behavior leads to positive associations that translate into an excellent evaluation of service and that CSR is a right way of differentiation. It is a powerful tool of creating affective responses which support loyalty.

Customer loyalty usually includes the behavioural aspect and the attitudinal aspect (Szczepańska \& Gawron, 2011; Martinez \& Rodríquez del Bosque, 2013). Szczepańska and Gawron (2011) maintain that behavioral loyalty shows customers' actions, which included repurchasing and readiness to engage in word-of-mouth. Besides, the behavioral dimension is associated with repetitive dealings from the customer in a specific period.

However, repeated behavior might be because of satisfactions or just to the absence of alternatives, or due to convenience or a habit. Hence, the behavioral loyalty approach is criticized on the basis that it can lead to loyalty behavior such as spurious loyalty or even no loyalty (Martinez \& Rodríquez del Bosque, 2013; Dick \& Basu, 1994, p.100). 
DOI: $10.14807 /$ ijmp.v12i8.1502

Stanisavljević (2017) contend that the attitudinal aspect of customer loyalty means an upbeat of the company is made. This creates an emotional connection between the customer and the company, hence a good loyalty. Similarly, Yuen, Thai and Wong (2016) contend that attitudinal loyalty encompasses a sense of dedication, engagement, and adherence to a brand. Nevertheless, the attitudinal loyalty is criticized on the ground that a customer's positive attitude towards a specific product or service might not assure repeat patronage or purchase frequency (Dick \& Basu, 1994).

Customer loyalty is measured using behavioral loyalty measurement, attitudinal loyalty measurement, and composite loyalty measurement (Szczepańska \& Gawron, 2011; Mandhachitara \& Poolthong, 2011). According to Yuen et al. (2016), behavioral loyalty measurements include positive, real actions like repurchase or recommendation of products or services to others.

The attitudinal loyalty measurements is measured by include the intent to purchase another time and, or purchase extra products or services from the same company, readiness to recommend the company to others, and a commitment to the company demonstrated by a resistance to switching to a competitor (JR, Bush \& Ortinau 2009).

Finally, the composite customer loyalty is measured by the combining of the behavioral loyalty and attitudinal loyalty. Proper loyal incorporates behavioral loyalty and attitudinal loyalty, resulting in consistent attitudes and behaviors of loyalty (Berg \& Lidfors, 2012). Hence, in this study, the composite measurement of customer loyalty is adopted.

\subsection{Gratitude}

Jain and Jaiswal (2016) define gratitude as "the sense of appreciation experienced by someone who has received a material gift or benefits from another person” (p.127). It is argued that gratitude is a necessary social element of human dealings that provides an emotional underpinning for reciprocal behaviors (Palmatier, Jarvis, Bechkoff \& Kardes, 2009).

Gratitude is a result of human relations that provides an emotional foundation for reciprocal actions (Simon (2013). acknowledged that gratitude operates usually when people are the beneficiaries of pro-social behavior. People experience gratitude generally when they observe that a benefactor has acted to improve their well being (McCullough, Kilpatrick, Emmons \& Larson, 2001). 
Gratitude regulates people's responses to favors obtained by inspiring them to recognize verbally and nonverbally and by encouraging them to extend benefits to their benefactor in kind (McCullough, Kimeldorf \& Cohen, 2008).

McCullough et al. (2001) contend that gratitude has specific significant moral roles, which include a moral barometer, a moral motive, and a moral reinforcing role. The moral barometer role explains that gratitude arises when one benefits from another person's moral actions. The moral motive role explains that gratitude encourages pro-social behavior in the beneficiary either directly to the benefactor or others, and finally, the moral reinforcer role of explains that showing gratitude to someone for his or her pro-social actions produces more effort on the side of the benefactor to behave morally in the future.

People feel and express gratitude in three ways. Firstly, they can get back positive memories and being thankful for elements of past blessings, and secondly, they can be thankful for current blessings. Finally, they can relate it to the future (maintaining a hopeful and optimistic attitude) (Jain \& Jaiswal, 2016).

Previous studies have implicated the construct of gratitude into CSR and customers' positive outcomes relationship as an underlying mechanism of influence (Romani, et al., 2013; Xie, et al., 2015; Choi \& Park, 2016; Xie, et al., 2019). Overall, previous findings have showed positive mediating role of gratitude. Nonetheless, further examination is needed in this direction as little is known on the mediating role of gratitude in the banking services context.

\section{THEORETICAL FRAMEWORK AND HYPOTHESES DEVELOPMENT}

\subsection{Theoretical framework of the study}

\subsubsection{The stakeholder theory of CSR}

In this study, the stakeholder theory of CSR is used to explain to possible link between ESCR and customer loyalty. The pioneer of the stakeholder theory of CSR was R. Edward Freeman (Jones, 1995). This theory claim that business managers must meet diverse groups (e.g., customers, local community) who can influence firms outcomes.

Hence, it can be advantageous for the firms to undertake specific corporate social responsibility activities that non-financial stakeholders regard as essential or else these groups may withdraw their support for the firm (Slavova, 2013). According to the stakeholder theory, the task of a corporation is to generate profits for owners and provide a variety of benefits that are cherished by its customers and other stakeholders (Bhattacharya, Korschun \& Sen, 2009). 
DOI: 10.14807/ijmp.v12i8.1502

\subsubsection{The moral affect theory of gratitude}

In this study, the moral affect theory of gratitude (hereafter referred to as MATOG) is used to explain the connections between ECSR, gratitude, and customer loyalty, and the mediating role of gratitude. MATOG was introduced by Mccullough, Kilpatrick, Emmond, and Larson, (Tian, Du \& Huebner, 2015). Mccullough, Kilpatrick, Emmond and Larson (2001) contend that gratitude as a moral affect has three specifics a moral barometer function, a moral motive function, and a moral reinforcing function.

First, the moral barometer role postulates that gratitude arises when a person observes that he has benefitted from someone's valuable actions. Second, moral motive role of gratitude posits that gratitude has a motivational value. People that benefited from the good gestures of a benefactor tend to promote the interest of the benefactor. Finally, moral reinforcer role of gratitude postulates that showing gratitude to someone's valuable actions creates more tremendous effort on the side of the benefactor to behave morally in the future.

\subsection{Hypotheses development}

\subsubsection{The relationship between ECSR and Customer loyalty}

This study adopted the stakeholder theory of CSR to explain the effect of ECSR on CL. ECSR concerns the essential principles of honesty, fair conduct, respect, and transparency (Lentner, Sezdegi \& Tatay, 2015). García de los Salmones and Rodríguez del Bosque (2011) claim that the perception of ethically responsible behavior leads to positive associations that translate into an excellent evaluation of service. Business institutions practice ECSR, for instance, by giving customers full and correct information regarding their products and services, apply protective measures to process customers' sensitive personal information, among others (Park, Kim \& Kim, 2017).

Businesses implementing ethical practices are cherished and supported by customers. Kodua, Narteh, Braimah \& Mensah, 2016) found and reported that ECSR initiatives of companies have a positive and significant effect on customer loyalty. In contrasts, Stanisavljević (2017) and McCain et al. (2019) found and reported that ECSR do not influence customer loyalty. Based on the preceding discussions, the below hypothesis $(\mathrm{H})$ is proposed.

- H1: ECSR has a positive effect on customer loyalty.

\subsubsection{The relationship between ECSR and customer gratitude}


INDEPENDENT JOURNAL OF MANAGEMENT \& PRODUCTION (IJM\&P)

http://www.ijmp.jor.br

v. 12, n. 8, November-December 2021

ISSN: $2236-269 X$

DOI: $10.14807 /$ ijmp.v12i8.1502

Firms commitment to ECSR, for instance, treat their customers fairly, they are honest in handling customer issues. Consequently, ECSR practices can lead to excellent evaluation of service (García de los Salmones \& Rodríguez del Bosque, 2011). Moreover, customers can perceive benefits by viewing firms' ECSR practices as promoting their own moral interest. Consequently, in line with the moral barometer role of gratitude, feelings of gratitude can arise in customers. Romani et al. (2013) found and reported a positive and significant direct influence of ECSR practices on customers' feelings of gratitude. Xie et al. (2019) found and reported that ECSR actions positively influence customers' felt gratitude. Hence, it is hypothesized as follows.

- H2: ECSR has a positive effect on customer gratitude.

\subsubsection{The relationship between customer gratitude and customer loyalty}

The moral motive role of gratitude postulates that gratitude has a motivational value. Accordingly, people that made grateful by the actions of a benefactor might promote the interests of the benefactor (or a third party) in the future (McCgollough, et al., 2001). Thus, gratitude functions to foster social relations through its support of reciprocal or pro-social behavior between a benefactor and beneficiary (Barlett \& DeSteno, 2006), and the feelings of gratitude might become the basis of long term associations between the beneficiary and the benefactor (Dewani, Sinha \& Mathur, 2016).

Huang (2015) found and reported that felt gratitude positively affected behavioral loyalty. Dewani et al. (2016) found and reported that feelings of gratitude in customers positively influence immediate purchase intentions and customer loyalty. Likewise, Xie et al. (2019) found and reported the positive influence of gratitude on customers' brand advocacy behaviors. Hence, it is proposed as follows.

H3: Customer gratitude has a positive effect on customer loyalty.

\subsubsection{Mediating role of customer gratitude between ECSR and customer loyalty}

This study adopted the barometer and moral motive functions of gratitude to explain the mediating role of customer gratitude between ESCR and customer loyalty. The moral barometer role of gratitude posits that gratitude arises due to the observation that one has been a beneficiary of another person's moral action. On the other hand, the moral motive function of gratitude postulates that gratitude encourages pro- social behavior in the beneficiary either directly to the benefactor or others (McCullough, et al., 2001). 
DOI: 10.14807/ijmp.v12i8.1502

ECSR practices can engender feelings of gratitude, and then, gratitude felt might influence customers to show loyalty (Romani, et al., 2013). Romani et al. (2013) reported that the effect of perceived ECSR actions on customers is mediated by customers' felt gratitude. Similarly, Xie et al. (2019) found and reported mediation of gratitude on the association between ECSR activities and customers' advocacy behaviors. Based on the preceding discussions, it is proposed as follows:

H4: Customer gratitude mediates the relationship between ECSR and customer loyalty

\subsubsection{Proposed Conceptual model of the study}

Figure 1 illustrate the proposed conceptual model of this study. The proposed model allows ECSR to influence customers' loyalty indirectly through the mediation of customer gratitude. The arrows are the hypothesized paths.

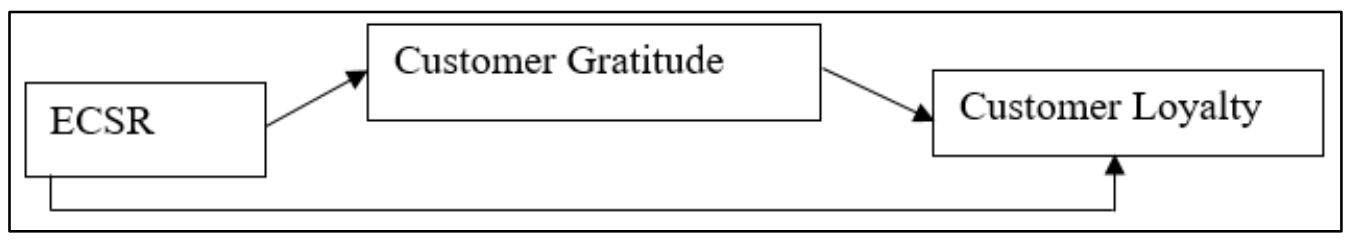

Figure 1: Proposed conceptual model of the study

\section{METHODOLOGY}

The study adopted a cross-sectional survey research method and collected data in 2019. The survey approach was employed because it gives a fast, cheaper, and correct means of obtaining information about a population (Zikmund et al., 2007). Also, this study examined the ECSR practices of the Nigerian retailing banks in north-eastern region of Nigeria. The zone was selected because there is a dearth of studies similar to this present study in the zone. Specifically, data were collected in Bauchi, Damaturu, Gombe, Maiduguri, Jalingo, and Yola metropolitan towns because large concentration of retail banks.

Individual customers of the retail banks in the study area constituted the population of this study. 500 individual customers were chosen as sample, using a convenience sampling method. Structured questionnaire was used in this survey. Part one sought information regarding the characteristics of respondents, while part two relates to information regarding the constructs of the study. Measures for the constructs were adapted from previous studies.

Measures for ECSR were borrowed from Tong, Wong \& Hsiang (2017), Kim, Song, Lee \& Lee (2017), Mulaessa and Wang (2017) and Salmones et al. (2005). Measures for Customer Gratitude (GRAT) were sourced from Dewani et al. (2016). Customer loyalty (CL) 
DOI: 10.14807/ijmp.v12i8.1502

indicators were borrowed from Chang and Yeh (2017). All the measurement items were rated on a five-point Likert scale, ranging from ‘strongly disagree’(1) to ‘strongly agree’(5).

Before full scale administration of the questionnaire to respondents, the questionnaire was given for face validity to research experts who accordingly validated it. Additionally, the questionnaire was pilot tested with a sample of 100 individual bank customers. Internal consistency reliability of the measurement was tested using Cronbach's alpha. Result revealed the following values: ETR (6 items= 0.801); GRAT (4items=0.887) and CL (6 items $=0.914$ ). Since, the values of the construct have exceeded the cut off limit of 0.7(Pallant, 2005), the instrument was deemed reliable.

This present study employed procedural and statistical methods to manage the potential problems of common method variance. Common method bias has been considered as a major source of measurement error and thus a threat to the model validity, particularly in self-report studies (Podsakoff \& Organ, 1986). The common method bias can be attributed by respondents (e.g. social desirability), item characteristics (e.g., vague items), and context (e.g., induced mood), and measurement context (e.g., time and location of measurement) (Podsakoff, MacKenzie, Lee \& Podsakoff, 2003).

Regarding the procedural method, this study ensured clarity in wordings, and assuring the privacy of the respondents. Concerning the statistical procedure, the Harman's one-factor statistical test was used to assess the impact of this bias. This technique was chosen because it is the most straightforward measure, and the most widely used (Podsakoff, et al., 2003). The test showed that the first component (\% of the variance value) accounts for less than $50 \%$ i.e., $43.235 \%$ of all variables in the model.

Hence, it is free from significant common method bias effects. The Partial Least Squares (PLS) structural equation modeling was employed to test hypotheses. PLS was chosen because of its relative robustness in working with smaller and large samples. Also, PLS has a few limiting assumptions regarding model specifications and data normality (Aramburu \& Pescador, 2017).

\section{RESULTS}

\subsection{Preliminary analysis}

Five hundred copies of the questionnaire were distributed, out of which 430 copies, representing 86 percent (\%) response rate were retrieved as useable analysis. Before the analysis, the data were examined for missing values. The percentage of missing values in this 
DOI: 10.14807/ijmp.v12i8.1502

study's data set is considered non-significant as it is far below the fair value of $5 \%$ (Tabachnick \& Fidell, 2007). More importantly, as the missing values occurred randomly and not based on a systematic pattern, the researcher may opt to replace the missing values (Pallant, 2010). Thus, as these missing values were less than $5 \%$ and had occurred completely the random pattern, the study replaced the values using mean substitution as suggested in (Hair, et al., 2010; Tabachnick \& Fidell, 2007).

\subsection{Profile of the respondents}

Results in Table 2 showed that 271(63\%) are male, while 156(36.3\%) are female. Furthermore, the majority of the respondents, 174(40.4\%), are within the age bracket of 18-27. Concerning the level of education, the majority of the respondents, 176(41\%), hold bachelors' degree. Regarding a monthly income level, 144(33.5\%) of the respondents earn monthly income within NGN 10,000 and NGN 20,000. Regarding the period of maintaining a bank account, 241(56\%) of the respondents, constituting the majority, maintain bank account for seven years and above.

Table 2: Profile of Respondents

\begin{tabular}{lcc}
\hline Variables & Frequency & (\%) \\
\hline Gender & 271 & 63 \\
Male & 156 & 36.3 \\
Female & 3 & 0.7 \\
Missing values & $\mathbf{4 3 0}$ & $\mathbf{1 0 0}$ \\
Total & & \\
\hline Age & 174 & 16 \\
18-27years & 163 & 24 \\
$38-37$ & 45 & 10.5 \\
$38-47$ & 41 & 9.5 \\
48 and above & 7 & 1.6 \\
Missing Values & $\mathbf{4 3 0}$ & $\mathbf{1 0 0}$ \\
Total & & \\
\hline Level of Education & 52 & 12.1 \\
Secondary & 121 & 28.1 \\
Diploma & 176 & 40.9 \\
Bachelor Degree & 20 & 4.7 \\
Master Degree & 4 & 0.9 \\
Professional & 49 & 11.4 \\
Others & 8 & 1.9 \\
Missing Values & $\mathbf{4 3 0}$ & $\mathbf{1 0 0}$ \\
Total & & \\
\hline Income & 144 & 33.5 \\
10,000-20,000 & 100 & 23.3 \\
21,000-30,000 & 57 & 13.3 \\
31,000-40,000 & 26 & 6 \\
41,000-50,000 & &
\end{tabular}


ISSN: 2236-269X

DOI: 10.14807/ijmp.v12i8.1502

\begin{tabular}{lcc}
51,000 and above & 83 & 18.8 \\
Missing Values & 20 & 3.7 \\
Total & $\mathbf{4 3 0}$ & $\mathbf{1 0 0}$ \\
\hline Duration of Bank Account & & \\
Less than I year & 35 & 8.1 \\
1-3 years & 105 & 24.4 \\
4-6yeard & 36 & 23.5 \\
7 years and Above & 241 & 45 \\
Missing Values & 20 & 3.1 \\
Total & $\mathbf{4 3 0}$ & $\mathbf{1 0 0}$ \\
\hline
\end{tabular}

\subsection{Reliability and validity analysis}

Exploratory factor analysis using maximum likelihood with Promax was used to test the validity of indicators. Kaiser-Meyer-Olkin (KMO) value and Bartlett's test of sphericity were used to determine sampling adequacy and correlations in the data before the factor analysis. Table 3 showed that the KMO values for all the constructs were 0.866 , which thus acceptable values thus satisfactory for factor analysis (Kaiser, 1974). The Bartlett's test of sphericity is significant $(\mathrm{p}<0.01)$; indicating good correlations in the data for factor analysis.

Table 3: KMO and Bartlett's test of sphericity

\begin{tabular}{|l|l|l|}
\hline KMO Measure of Sample Adequacy & .866 \\
\hline Bartlett's Test of Sphericity & Approx. Chi-Square & 3700.966 \\
\cline { 2 - 3 } & Df & 171 \\
\cline { 2 - 3 } & Sig. & .000 \\
\hline
\end{tabular}

The outer loadings were examined for the indicators' reliability. The results showed that all loading values exceeded the suggested threshold value of 0.60 and above (Hair Jr. et al., 2014). Hence, the reliability of the indicators had been assumed, as seen in Table 4. Also, Cronbach's alpha $(\alpha)$ was used to verify the internal consistency reliability of the items. The result of the internal consistency reliability values of the constructs as presented in Table 5.3 were $\mathrm{ETR}=0.86$, GRAT $=0.72$, and $\mathrm{CL}=0.90$. These values revealed good reliability as they exceeded the required threshold of 0.7 (Pallant, 2005).

Regarding composite reliability (CR), the reliability scores were found to be above the threshold of 0.70 . Hence, each construct in the model has captured indicators that have much in common, and they are statistically significant (Hair Jr. et al., 2014). An assessment of convergent validity was also conducted by examining the average variance extracted (AVE) values. All the AVE values in the results exceeded the threshold value of 0.50 (Hair Jr. et al., 2014). The least value was 0.51 , and hence, convergent validity was established. Table 5.3 contains the AVE values. 
INDEPENDENT JOURNAL OF MANAGEMENT \& PRODUCTION (IJM\&P)

http://www.ijmp.jor.br

v. 12, n. 8, November-December 2021

ISSN: 2236-269X

DOI: 10.14807/ijmp.v12i8.1502

Table 4: Item loadings, $\alpha, \mathrm{CR}$, and AVE

\begin{tabular}{|c|c|c|c|}
\hline Construct & Indicators & $\begin{array}{l}\text { Factor } \\
\text { loading }\end{array}$ & $\alpha, \mathrm{CR}, \mathrm{AVE}$ \\
\hline \multirow[t]{6}{*}{ ECSR } & 1.The bank respects customer human rights & 0.71 & \multirow{6}{*}{$\begin{array}{c}\alpha=0.86 \\
C R=0.80 \\
\text { AVE }=0.51\end{array}$} \\
\hline & $\begin{array}{l}\text { 2.The bank has established ethical guidelines for business } \\
\text { activities }\end{array}$ & 0.62 & \\
\hline & 3.The bank makes effort to fairly treat customers & 0.67 & \\
\hline & 4.The bank is honest to its customers & 0.76 & \\
\hline & $\begin{array}{l}\text { 5.The bank respects ethical principles in any transaction with } \\
\text { customer }\end{array}$ & 0.77 & \\
\hline & 6.The bank tries to become an ethically trust worthy bank & 0.72 & \\
\hline \multirow[t]{4}{*}{ GRAT } & 1.I feel grateful to the bank for the benefits provided & 0.83 & \multirow{4}{*}{$\begin{array}{c}\alpha=0.87 \\
C R=0.91 \\
\text { AVE }=0.72\end{array}$} \\
\hline & 2.I am thankful to the bank for the benefits that are provided & 0.86 & \\
\hline & 3.I feel appreciative to the bank for the benefits it provides & 0.85 & \\
\hline & $\begin{array}{l}\text { 4.I feel the desire to say 'thank you' to the bank for the benefits } \\
\text { that are provided }\end{array}$ & 0.86 & \\
\hline \multirow[t]{6}{*}{ CL } & 1.I am a loyal customer of this bank & 0.70 & \multirow{6}{*}{$\begin{array}{l}\alpha=0.90 \\
C R=0.87 \\
\text { AVE }=0.60\end{array}$} \\
\hline & 2. I intend to remain a customer of this bank & 0.78 & \\
\hline & 3.This bank is my first choice when I travel between cities & 0.80 & \\
\hline & 3.I am likely to say positive things about this bank & 0.73 & \\
\hline & 4.I will recommend this bank to my family members and friends & 0.83 & \\
\hline & ke & 0.82 & \\
\hline
\end{tabular}

To establish discriminant validity of the reflective constructs, the square root of AVE of each variable should be higher than its correlations with any other construct (Fornell \& Larcker, 1981). Table 5 showed the diagonal bolded values as the square root of AVE. Each value is above the correlation of any reflective variable with one another. This indicates the distinctiveness of each of these constructs.

Table 5: Discriminant validity

\begin{tabular}{lccc}
\hline Variables & CL & ETR & GRAT \\
\hline CL & $\mathbf{0 . 7 8}$ & & \\
ETR & 0.54 & $\mathbf{0 . 7 1}$ & \\
GRAT & 0.56 & 0.46 & $\mathbf{0 . 8 5}$ \\
\hline
\end{tabular}

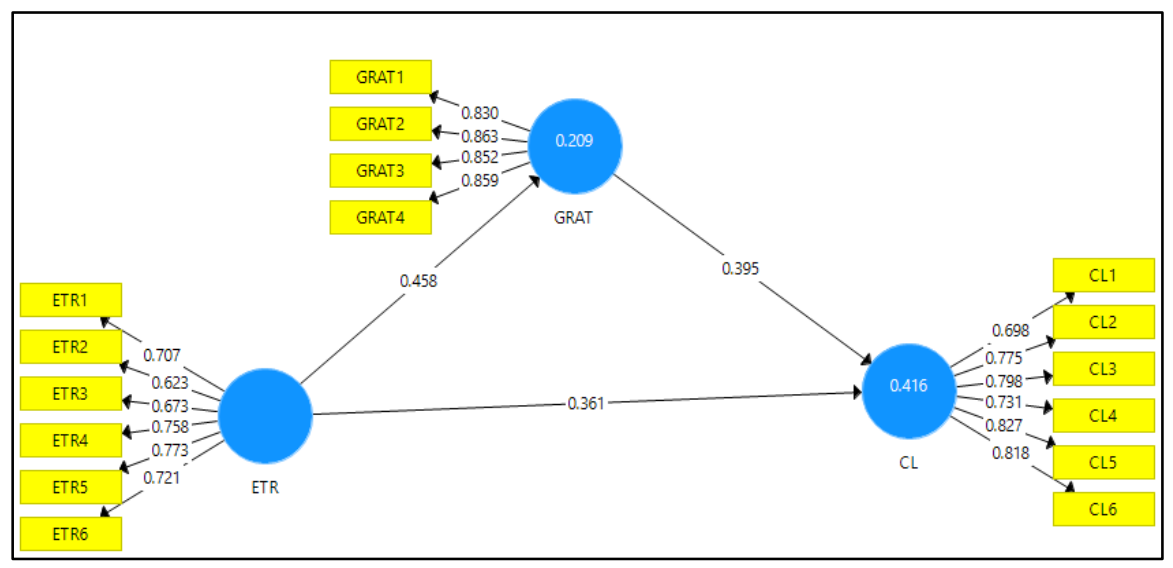

Figure 2: PLS Algorithm

\subsection{Structural Model}

The coefficients were estimated through bootstrapping procedure set at 5,000 subsamples of 430 cases in the data set and a no sign change. 
DOI: 10.14807/ijmp.v12i8.1502

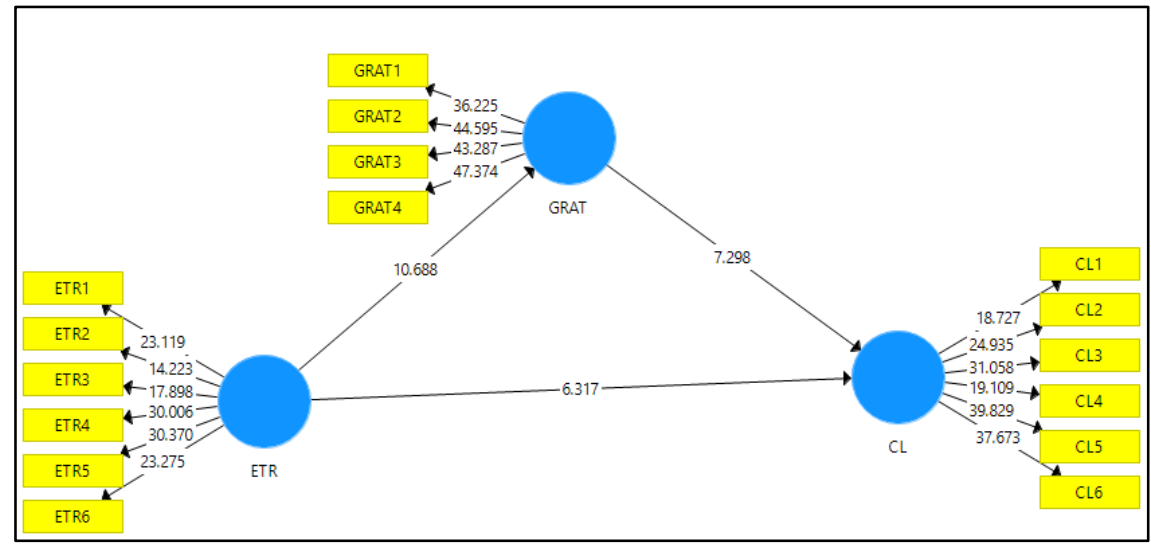

Figure 3: PLS Bootstrapping

Table 6: Result of hypotheses test

\begin{tabular}{lcccc}
\hline R/Ship & Beta Values & Standard Deviation & T Statistics & P Values \\
\hline ETR -> CL & 0.36 & 0.06 & 6.31 & 0.00 \\
ETR -> GRAT & 0.46 & 0.04 & 10.69 & 0.00 \\
GRAT -> CL & 0.40 & 0.05 & 7.30 & 0.00 \\
ETR -> GRAT->CL & 0.18 & 0.03 & 6.30 & 0.00 \\
\hline R square & 0.42 & & \\
\hline
\end{tabular}

The result in Table 5.5 showed that a significant positive relationship exists between ECSR and CL $(\mathrm{t}=6.31>1.96, \mathrm{P}=0.00<0.05)$. Hence, $\mathbf{H 1}$ was accepted. Similarly, a positive and significant relationship was found between ECSR and GRAT $(\mathrm{t}=10.69>1.96, \mathrm{P}=0.00<0.05)$. Consequently, $\mathbf{H} 2$ was accepted. The empirical analysis also supported the relationship between GRAT and CL ( $\mathrm{t}=7.30>1.96, \mathrm{P}=0.00<0.05)$. Thus, $\mathbf{H 3}$ was accepted.

Regarding of mediating role of GRAT, a significant and positive mediation was found on the relationship between ECSR and CL $(\mathrm{t}=6.30>1.96, \mathrm{P}=0.00<0.05)$. Thus, GRAT is a good explanation of the reason why ECSR is related to CL. Hence, $\mathbf{H} \mathbf{4}$ was accepted. Following this mediation result, it is concluded that GRAT partially mediates the relationship between ECSR and CL because both the direct and indirect relationships is all significant.

Also, the empirical analysis showed that the coefficient of determination $\left(\mathrm{R}^{2}\right)$ for the endogenous variables is 0.42. Hence, the exogenous latent variables (ETR and GRAT) are good predictors of the endogenous latent variable (CL).

Table 7: Effect size

\begin{tabular}{lcc}
\hline Variables & F2 & Effect size \\
\hline ETR & 0.176 & Medium \\
GRAT & 0.211 & Medium \\
\hline
\end{tabular}

Again, the exogenous construct, ETR and GRAT had the effect size values of 0.17 and 0.21 respectively. Based on the argument of Cohen (1988), $\mathrm{f}^{2}$ values of 0.02, 0.15, and 0.35, indicate small, medium, and large effects. Therefore, the effect sizes of ETR and GRAT on the endogenous construct CL are medium and medium, respectively. 
INDEPENDENT JOURNAL OF MANAGEMENT \& PRODUCTION (IJM\&P)

http://www.ijmp.jor.br

v. 12, n. 8, November-December 2021

ISSN: 2236-269X

DOI: 10.14807/ijmp.v12i8.1502

Table 8: Predictive Relevance

\begin{tabular}{lllc}
\hline Variable & SSO & SSE & $\mathbf{Q}^{\mathbf{2}}$ (=1-SSE/SSO) \\
\hline CL & $2,580.00$ & $1,978.98$ & 0.233 \\
\hline
\end{tabular}

The predictive relevance was measured by the Stone-Geisser criterion $\mathrm{Q}^{2}$ value, obtained using the blindfolding procedure (Hair Jr, et al., 2014). Using the cross-validated redundancy approach, as recommended by Hair Jr et al. (2014), the two reflective exogenous constructs had proven to have adequate predictive relevance as their values of $\mathrm{Q}^{2}$ had been above zero.

\section{DISCUSSION AND CONCLUSION}

\subsection{Discussion}

The result of this study has shown that ECSR has a positive influence on CL toward the retail banks in Nigeria. This implies that the individual customers showed loyalty towards Nigerian retail banks for practicing ECSR. Customers would tend trust that the ethical brand sincerely provides the products' and or services’ quality thus leading to an excellent evaluation (Salmones \& Bosque, 2011; He \& Lai, 2014).

Hence, managers of Nigerian retail banks should continuously develop and appraise their ECSR strategies, and maintain ECSR as an essential component of their banking business. The finding that ECSR positively influences CL was in agreement with that of Lee et al. (2017) and Kodua et al. (2016). In contrast, Stanisavljević (2017) and McCain et al. (2019) found and reported that ECSR does not influence CL.

Also, the results revealed that ECSR is positively related to GRAT. This finding implies that individual customers of Nigerian retails banks value ethical practices and banks' resources being directed to ethical issues. This finding is consistent with that of Romani et al. (2013) and Xie and Bagozzi (2014). Furthermore, it was revealed that there was positive and significant relationship between GRAT and CL.

This means that felt gratitude experienced by customers due to resources diverted by the banks to ECSR issues influenced customers' loyalty. Gratitude motivates customers to make encouraging associations with organizations (Faza-e-Hasan, Lings, Mortimer \& Neale, 2017), hence, the observed CL toward Nigerian retail banks. This is consistent with the moral motive role of gratitude. This role posits that when customers feel grateful upon receipt of benefits from companies, they reciprocate by displaying behaviors that support the companies (Romani, et al., 2013). The finding that felt gratitude influenced CL concurs with Simon (2013) and Park and Choi (2016). 
DOI: 10.14807/ijmp.v12i8.1502

Also, the results revealed that GRAT mediated the effect of ECSR on CL. This finding means that ECSR initiatives engendered feelings of gratitude in individual customers. Consequently, the gratitude felt encouraged CL towards Nigerian retail banks. More importantly, this finding implies that individual customers attach significance to ECSR initiatives. Consequently, managers of Nigerian retail banks should observe customer reactions and emphasize responses of gratitude in communications to take advantage of customers' feeling of gratitude. The finding that GRAT mediates the relationship between ECSR and CL and related customer positive outcomes such as advocacy and recommendation behaviors is consistent with that of Romani et al. (2013) and Xie and Bagozzi (2014).

\subsection{Theoretical implications}

This study contributes to theory in the following ways. First, in this study, the focus has been on the Nigerian retail banking industry, since the study interprets the topic of ECSR as highly relevant for this industry, the study has provided an understanding of the positive connection between engagement in ECSR activities and customer loyalty in this particular industry. Second, this study proposes a mediated mechanism for enhancing CL toward retail banks, which incorporates GRAT as a mediator.

It applies MATOG to associate ECSR and CL. Hence, this study enables a better understanding of this theory in the retail banking sector. The addition of gratitude into ECSR theory in this study is essential because it shows the usefulness of ECSR practices is based also on emotional ones. Thus, the finding of this study adds to the body of knowledge regarding the mediation of GRAT between ECSR and CL. Finally, this study developed and tested a new theoretical framework which attempted to bridge the knowledge by addressing the value of ECSR driver of GRAT, and CL, as they are hardly ever examined in the literature.

\subsection{Managerial implications}

The findings of this present study contribute to managerial practice in the following ways. First, to get the most out of a financial performance in the marketplace, this study has confirmed that Nigerian retail banks should put greater interest to ECSR activities that target customers. This will add to superior ECSR perception, and CL, which are beneficial to generating profits. Second, findings in this study demonstrate that Nigerian retail banks perform an essential role in the everyday lives of the customers and can influence their behaviors. 
DOI: $10.14807 /$ ijmp.v12i8.1502

Specifically, by paying attention to ECSR, managers of Nigerian retail banks can achieve GRAT and CL. More importantly, since the role of GRAT is evident, this finding will help managers of Nigerian retail banks to develop ECSR initiatives which strongly create feelings of gratitude among their banks' customers in order to take advantage of such positive emotions, and eventually cultivate CL. Finally, the findings of this study will help marketing staff of Nigerian retail banks in identifying effective and efficient ways to build a long-lasting relationship with customers and gain a sustainable competitive advantage.

\subsection{Limitations and future research}

First, this study adopted cross section survey where data were collected at single point in time. Thus, the findings of this study cannot disclose CL toward Nigerian retail banks over a long period. Second, this study surveyed individual customers of the retail banks. Thus, findings cannot provide information regarding corporate customers' responses to the ECSR actions of Nigerian retail banks. Finally, this study was conducted in the banking services sector. Consequently, no information is received concerning the mediating role of GRAT between ECSR and CL in other services sectors (e.g., communications, transport, etc.), and manufacturing sector.

In order to overcome the above limitations, it is suggested that future research works should adopt longitudinal survey so that the loyalty of the customers of Nigerian retail banks as an outcome of ECSR actions over an extended period of time will be known. Also, it is recommended that future studies should survey the CL of corporate customers in the context of ECSR activities of Nigerian retail banks. The corporate customers are an essential segment of retail banks because they are considered high net worth customers.

Finally, future research works should test this study's theoretical framework in the nonbanking services sector of the country. Surveying the ECSR activities of the different industries is essential because it is contended that the effect of specific CSR dimensions might have different outcome on industries depending on the sensitivities of each industry (Goyal \& Chanda, 2017).

\section{CONCLUSION}

The core purpose of this study was to investigate the mediating role of GRAT on the effect of the ECSR actions of Nigerian retail banks on CL. The result of this shows GRAT mediated between ECSR and CL. This finding implies that ECSR initiatives of Nigerian retail banks can attract CL and GRAT, and ultimately enhancing the banks' more fantastic 
DOI: 10.14807/ijmp.v12i8.1502

profitability position. Therefore, the study concludes that interest in ECSR initiatives is essential task that lead to loyalty.

The result contributes to the understanding of ECSR practices on customers. In today's highly competitive business environment, including that of Nigeria, the retail banks and other business institutions need to match their marketing actions with ECSR activities to gain competitive advantage. Hence, it is recommended that ECSR initiatives be practiced by Nigerian retail banks as a tool for creating competitive advantage and attracting lasting customer loyalty. Also, managers of Nigerian retail banks should publicize their ECSR activities to maximize returns from ECSR.

\section{REFERENCES}

Aramburu, A. A., \& Pescador, I. G. (2017).The effects of corporate social responsibility on customer loyalty: The mediating effect of reputation in cooperative banks versus commercial banks in the Basque country, Journal of Business Ethics, 154(3), 701-719.

DOI.10.1007/s10551-017-3438-1

Afrinvest, (2018). The virtuous cycle-again! The Nigerian economy and financial market/2017 review \& 2018 outlook. Retrieved From: https://www.afrinvest.com/.../2018/.../Nigerian-Economy-and-Financial-Market-2017-...

Barlett, M. Y., \& DeSteno, D. (2006). Gratitude and pro social behavior helping when it costs you, Psychological Science, 17(4), 319-325. Retrieved from: https //www.uwc.ac.za

Berenbeim, R. E. (2006). Business ethics and corporate social responsibility defining an organization's ethics brand. Address delivered to the Ethics and Compliance Conference New York, May 12, 2006. Retrieved from: https //www.uwc.ac.za

Berg, H., \& Lidfors, L. (2012). The effect of perceived corporate social responsibility on customer loyalty an empirical study into consumer behaviour on the Swedish chocolate market, Thesis for the award of master degree in Marketing, Linnæus University. Retrieved from: www.diva-portal.org/smash/get/diva2:533436/FULLTEXT01.pdf

Bhattacharya, C. B., Korschun, D., \& Sen, S. (2009). Strengthening stakeholder-company relationship through mutually beneficial corporate social responsibility initiatives. Journal of Business Ethics, 85, 257-272. DOI 10.1007/s10551-008-9730-3

Bhattacarya, C. B., \& Sen, S. (2004). Doing better at doing good: When, why, and how consumers respond to corporate social initiatives, California Management Review, 47(1), 9-74. Retrieved from: www.davideacrowther.com/csrmodule/csrreading4b.pdf

Carroll, A. B. (1979). A three-dimensional conceptual model of corporate performance. Academy of Management Review, 4(4), 497-505. Retrieved from: URL: http://www.jstor.org/stable/257850

Carroll, A. B. (1991). The pyramid of corporate social responsibility: toward the moral management of organizational stakeholders. Business Horizon, 34(4), 39-48. Retrieved from: AB Carroll - Business horizons, 1991 - cf.linnbenton.edu 
DOI: 10.14807/ijmp.v12i8.1502

Carroll, A. B. (2016). Carroll's pyramid of corporate social responsibility: Taking another look. International Journal of Corporate Social Responsibility, 1(3), 1-8. DOI: 10.1186/s4099.016-004-6

Chang, Y. H., \& Yeh, C. H. (2017). Corporate social responsibility and customer loyalty in intercity bus services. Transport Policy, 59, 38-45.

http://dx.doi.org/10.1016/j.tranpol.2017.07.001

Dick, A. S., \& Basu, K. (1994). Customer loyalty: Toward an integrated conceptual Framework. Journal of the Academy of Marketing Science, 22(2), 99-113. Retrieved from: https://www.uwc.ac.za

Diwani, P. P. Sinha, P. K., \& Mathur, S. (2016). Role of gratitude and obligation in long term relationships. Journal of Retailing and Consumer Services, 31, 143-156.

http://dx.doi.org/10.1016/j.jretconser.2016.01.005.

Du, S., Bhattacharya, \& Sen, S. (2010). Maximizing business returns to corporate social responsibility (CSR): The role of CSR communication. International Journal of Management Reviews, 8-19. DOI:10.1111/j.1468-2370.2009.00276.x

Faza-e-Hasan, S. M., Lings, I. N., Mortimer, G., \& Neale, L. (2017). How gratitude influences customer word of mouth intentions and involvement: The mediating role of affective commitment. Journal of Marketing Theory and Practice, 25(2), 200-211. DI:10.1080/10696679.2016.1270769

Fornell, C., \& Larcker, D. F. (1981). Evaluating structural equation models with unobservable variables and measurement error. Journal of Marketing Research, 18(1), 3950. https://doi-org.ezproxy.uwc.ac.za/10.11771002224378810/800104

Goyal, P., \& Chanda, U. (2017). A bayesian network model on the association between CSR, perceived service quality and customer loyalty in Indian banking industry. Sustainable

Production and Consumption, 10, 50-65. http.dx.doi.org/10.1016/j.spc.2016.12.001

Salmones, M. M. G., \& Bosque, I. R. (2011). Corporate social responsibility and loyalty in services sector. EsicMarket, 138, 199-221. Retrieved from:

www.esic.edu/documentos/revistas/esicmk/110105_124149_I.pdf

Salmones, M. M., Crespo, A. H., \& Bosque, I. R. (2005). Influence of corporate social responsibility on loyalty and valuation of services. Journal of Business Ethics, 61, 369-385. DOI 10.1007/s10551-005-5841-2

Gunesh, R. V., \& Geraldine, R. W. (2015). Do corporate social responsibility practices of banks in Mauritius lead to satisfaction and loyalty? Studies in Business and Economics, 10(2), 128-144. DOI 10.1515/sbe-2015-0025

Hair, F. J. JR., Bush, R. P., \& Ortaniau (2009). Marketing research within a changing environment. 3rd edition, McGraw-Hill/Irwin, New York,

Hair, J. F., Black, W. C., Babin, B. J., \& Anderson, R. E. (2010). Multivariate data Analysis (7th ed.), Pearson Prentice Hall, New Jersey.

Hair Jr., J., Sarstedt, M., Hopkins, L., \& Kuppelwieser, V. G. (2014). Partial least squares structural equation modeling (PLS-SEM) An emerging tool in business Research. European Business Review, 26(2), 106-121. DOI 10.1108/EBR-102013-0128

He, Y., \& Lai, K. K. (2014). The effect of corporate social responsibility on brand loyalty: the mediating role of brand image. Total Quality Management, 25(3), 249-263.

http://dx.doi.org110.1080/14783363.2012.661138 
Huang, M. H. (2015). The influence of relationship marketing investments on customer gratitude in retailing. Journal of Business Research, 68, 1318-1323. http://dx.doi.org/10.1016/j.jusres.2014.12.081

Išoraite, M. (2016). Customer loyalty theoretical aspects. Ecoforum, 5(2), 292-299. Retrieved from: www.ecoforumjournal.ro > eco > article > download

Jain, M., \& Jaiswal, S. J. (2016). Gratitude: Concept, benefits and cultivation. International Journal of Engineering Technology Science and Research, 3(5), 207-211. Retrieved from: www.ijetsr.com/images/short_pdf/1463223114_giit295_ijetsr_(2).

Jones, T. M. (1995). Instrumental stakeholder theory: A synthesis of ethics and economics. Academy of Management Review, 20(2), 404-437. Retrieved from https://edisciplinas.usp.br/pluginfile.php/.../Ficha\%207_Jones\%20\%281995\%29.pdf

JR., J. F. H., Bush, R. P., \& Ortinau, D. J. (2009). Marketing research in a digital, information environment. edition 4. McGraw-Hill, Boston.

Kaiser, H. F. (1974). An index of factorial simplicity. Psychometrika, 39(1), 31-36. Retrieved from:

https://jaltcue.org/files/articles/Kaiser1974_an_index_of_factorial_simplcity.pdf

Kim, J., Song, H., Lee, K. L., \& Lee, J. Y. (2017). The impact of four CSR dimensions on a gaming company's image and customers' revisit intentions. International Journal of Hospitality Management, 61, 73-81. http.dx.doi.org/10.1016/j.ijhm.2016.11.005

Kim, S. B., \& Kim, D. Y. (2016). The influence of corporate social responsibility, ability, reputation, and transparency on hotel customer loyalty in the U.S.: A gender-based approach. SpringerPlus, 5(1537), 1-13. DOI 10.1186/s40064-016-32203

Kodua, P., Narteh, B., Braimah, M., \& Mensah, P. (2016). The role of corporate social responsibility in influencing brand loyalty in the Ghanaian telecommunication industry. Journal of Business and Economics, 7(11), 1895-1906. DOI: 10.15341/jbe (21557950)11.07.2016/015

Lentner, C., Szegedi, K., \& Tatay, T. (2015). Corporate social responsibility in the banking sector. Public Finance Quarterly, 1, 95-103. Retrieved from: https://www.researchgate.net/.../303697394_Corporate_Social_Responsibility_in_the_

Mandhachitara, R., \& Poolthong, Y. (2011). A model of customer loyalty and corporate social responsibility. Journal of Services Marketing, 25(2), 122-133.

DOI.10.1108/08876041111119840

Martinez, P., \& Bosque, I. R. (2013). Corporate social responsibility and customer loyalty: The roles of trust, customer identification with the company and satisfaction. International Journal of Hospitality Management, 35, 89-99.

http://dx.doi.org/10.1016/j.ijhm.2013.05.009

McCain, S. C., Lolli, J. C., Liu, E., \& Jen. (2019). The relationship between casino corporate social responsibility and casino loyalty. Tourism Economics, XX(X), 1-24.

DOI10.1177/1354816618808077

Mccullough, M. E., Kilpatrick, S. D., Emmond, R. A., \& Larson, D. B. (2001). Is gratitude a moral affect?. Psychological Bulletin, 27(2), 249-266. DOI.10.1037/00332909.127.2.249

McCullough, M. E., Kimeldorf, M. B., \& Cohen, A. D. (2008). An adaptation for altruism the social causes, social effects, and social evolution of gratitude. Current Directions in psychological Science, 17(4), 281-285. Retrieved from: www.uwc.ac.za 
McDonald, L. M., \& Rundle-T. (2008). Corporate social responsibility and bank customer satisfaction a research agenda. International Journal of Bank Marketing, 26(3), 170-182. Retrieved from: citeseerx.ist.psu.edu/viewdoc/download?doi=10.1.1.334.3070\&rep=rep1.

Moss, M. R. (2002). Spreading the ethical word, The Information Management Journal, 36(4), 42-46. Retrieved from: https://www.uwc.ac.za

Mulaessa, N., \& Wang, H. (2017). The effect of corporate social responsibility activities (CSR) on consumers purchase intention in China: Mediating role of consumer support for responsible business. International Journal of Marketing Studies, 9(1), 73-81. doi:10.5539/ijms.v9n/p73

Ogunowora, B., Stackhouse, M., \& Oh, W. Y. (2018). Media depictions of CEO ethics and stakeholders support of CSR initiative: The mediating roles of CSR motive attributions and cycinism. Journal of Business Ethics, 150, 525-540. https://doi.org/10.1007/s10551-0163173-z

Pallant, J. (2005). SPSS survival manual: A step by step guide to data analysis using spss for windows (version 12), Open University Press

Pallant, J. (2010). SPSS survival manual: a step by step guide to data analysis using SPSS (4th ed.), Open University Press, New York.

Palmatier, R. W., Jarvis, C. B., Bechkoff, J. R., \& Kardes, F. R. (2009). The role of customer gratitude in relationship marketing, Journal of Marketing, 73, 1-18. Retrieved from: https://pdfs.semanticscholar.org/91fb/df3a9852bc08fbc8836cb026df6Xb0b724.f

Pan, Y., Sheng, S., \& Xie, F. T. (2012). Antecedents of customer loyalty: An empirical synthesis and reexamination. Journal of Retailing and Consumer Services, 19, 150-158. Doi:10.1016/j.jretconser2011.11.004

Park, J. C., \& Choi, J. (2016). Relationship between corporate philanthropy and consumer loyalty-The mediating role of gratitude, trust and commitment: South Korean consumer perspectives. Academy of Marketing Studies Journal, 20(1), 11-17. Retrieved from: https://www.abacademies.org/articles/amsjvol20no12016.pdf

Podsakoff, P. M., MacKenzie, S. B., Lee, J. Y., \& Podsakoff, N. P. (2003). Common method biases in behavioral research: A critical review of the literature and recommended remedies. Journal of Applied Psychology. 88(5), 879-903. Retrieved from: www.researchgate.net > publication > 279796507_Comm

Romani, S., Grappi, S., \& Bagozzi, R. P. (2013). Explaining consumer reactions to corporate social responsibility: The role of gratitude and altruistic values. Journal of Business Ethics, 114, 193-206. DOI 10.1007/s10551-012-1337-z

Scheffer, J. (2002). Dealing with missing data. Research letters in the Information and Mathematical Sciences, 3, 153-160. Retrieved from: exec-ed.ac.nz > Colleges >IIMS > RLIMS > Volume03

Simon, F. (2013). The influence of empathy in complaint handling: Evidence of gratitudinal and transactional routes to loyalty. Journal of Retailing and Consumer Services, 20, 599608. http://dx.doi.org/10.1016/j.jretconser.2013.05.003

Slavova, I. (2013). Strategic perspective of corporate social responsibility. Economic Alternative. 13, 90-105. Retrieved from https://www.unwe.bg/uploads/Alternatives/A0903.2013.pdf 
DOI: 10.14807/ijmp.v12i8.1502

Stanisavljević, M. (2017). Does Customer loyalty depend on corporate social responsibility? NašeGospodarstvo/Our Economy, 63(1), 38-46. DOI:10.1515/ngoe-20170004

Szczepańska, K., \&Gawron, P. P. (2011). Changes in approach to customer loyalty. Contemporary Economics. 5(1), 60-69. DOI:10.5709/ce.1897-9254.5

Tabachnick, B. G., \& Fidell, L. S. (2007). Using multivariate statistics (5th ed.). Pearson, Boston

Tian, L., Du. M., \& Huebner, E. S. (2015). The effect of gratitude in elementary school students' subjective well-being in schools: The mediating role of pro social behaviour. Soc. Indic Res, 122, 887-904. DOI.10.1007/s11205-014-0712-9

Tong, C., Wong, A. T., \& Hsiang, L. C. L. L. (2017). The relationship between corporate social responsibility and customer satisfaction in Taiwan farmer association. Journal of Economics, Management and Trade, 18(20), 1-13. DOI:10.9734/JEMT/2017/34279

World Bank Group, (2017). Federal Republic of Nigeria diagnostic review of financial consumer protection key findings and recommendations. Retrieved from: documents.worldbank.org/.../pdf/125964-WP-P160136-PUBLIC-NIGERIADiagnosti...

Xie, C., \& Bagozzi, R. P. (2014). The role of moral emotions and consumer values and traits in the decision to support nonprofits. Journal of Nonprofit \& Public Sector Marketing, 26, 290-311. DOI:10.1080/10495142.2014.965064

Xie, C., Bagozzi, R. P., \& Gronhaug, K. (2015). The role of moral emotions and individual differences in consumer responses to corporate green and non-green actions. Journal of the Academy Marketing Science, 43, 333-356. DOI 10.1007/s11747-014-0934-5.

Xie, C., Bagozzi, R. P., \& Gronhaug, K. (2019). The impact of corporate social responsibility on consumer brand advocacy: The role of moral emotions, attitudes and individual differences. Journal of Business Research, 95, 514-530.

https://doi.org/10.1016/j.busres.2018.07.043

Yuen, K. F., Thai, V. V., \& Wong, Y. D. (2016). Are customers willing to pay for CSR? A study of individuals -specific mediators. Total Quality Management, 27(8), 912-926. http://dx.doi.org/10.1080/14783363.2016./187992

Zikmund, W. G., Ward, S., Lowe, B., \& Winzar, H. (2007), Marketing research Asia pacific edition, Cengage Learning Australia Pty Limited, South Melbourne. 